FULL RESEARCH ARTICLE

\title{
The distribution of anadromy and residency in steelhead/ rainbow trout in the Eel River, northwestern California
}

\author{
BRET HARVEY ${ }^{1 *}$, RODNEY J. NAKAMOTO ${ }^{1}$, ADAM J. R. KENT, $^{2}$ \\ AND CHRISTIAN E. ZIMMERMAN ${ }^{3}$
}

${ }^{1}$ USDA Forest Service, Pacific Southwest Research Station, 800 Buchanan Street, Albany, CA 94710, USA

${ }^{2}$ Oregon State University, College of Earth, Ocean, and Atmospheric Sciences, W. M. Keck Collaboratory for Plasma Mass Spectrometry, Corvallis, OR 97331, USA

${ }^{3}$ U.S. Geological Survey, Alaska Science Center, 4230 University Drive Suite 201, Anchorage, $A K$ 95508, USA

*Corresponding Author: bret.harvey@usda.gov

To inform management and conservation of the species, we investigated the distribution of anadromy and residency of steelhead/rainbow trout (Oncorhynchus mykiss) in the Eel River of northwestern California. We determined maternal anadromy versus residency for 106 juvenile O. mykiss using otolith microchemistry. To attempt to relate patterns of anadromy with environmental factors known to influence its distribution in O. mykiss in other places, fish were collected from 52 sites throughout the drainage covering a range of stream size $\left(0.1-7.7 \mathrm{~m}^{3} / \mathrm{s}\right.$ estimated mean annual run-off) and distance from the ocean (23-219 km). Sixty-one of 91 fish sampled below prospective barriers had anadromous mothers, while 1 of 15 fish sampled above barriers had an anadromous mother. We did not detect any influence of stream size or distance from the ocean on the occurrence of anadromy. Fish with resident mothers were found at 21 of 46 sites below barriers. The current broad distribution of fish with resident mothers indicates the importance of maintaining freshwater conditions suitable for resident adults and juveniles age- 1 and older, such as preserving dry-season streamflows.

Key words: anadromy, barriers, isotope analysis, life history Oncorhynchus mykiss, strontium

Extreme geographic and individual variability characterizes the life history of steelhead/rainbow trout (Oncorhynchus mykiss). For example, resident and anadromous individuals commonly co-occur in California (Donohoe et al. 2008; Zimmerman et al. 2009) and elsewhere (Zimmerman and Reeves 2000, 2002). Anadromous O. mykiss include two fundamentally different life histories, winter- and summer-run. Within these two anadromous 
life histories, individuals vary in the age of ocean entry, age of return to freshwater, and the extent of iteroparity. While it seems likely that the extreme variability of O. mykiss life history enhances the sustainability of the species, better understanding of this variability is needed to help prioritize conservation efforts (Knudsen and Michael 2009).

Understanding factors that influence the distribution and frequency of anadromy versus residency is an important area of research. Recent efforts have identified genetic variation associated with anadromous versus resident life histories (Hale et al. 2013; Pearse et al. 2014; Kannry et al. 2020; Kelson et al. 2020) and a variety of other individual and environmental factors that can alter the frequency of anadromy (Ohms et al. 2014; Sloat and Reeves 2014; Kendall et al. 2015). One study at the stream network scale in the John Day River Drainage in Oregon indicated that stream size influences the frequency of anadromy (Mills et al. 2012). Increasing residency in $O$. mykiss with distance upstream has been observed widely (e.g., McMillan et al. 2007), but in at least one case, the opposite trend has been observed (Liberoff et al. 2015). The influence of distance per se can be difficult to distinguish from other environmental factors. However, in some settings, variation in freshwater migration distance appears to influence anadromy in salmonids even over distances $<10 \mathrm{~km}$ (Kristoffersen 1994). The generality of any patterns of anadromy with stream size and migration distance remains to be resolved. For example, increasing residency with decreasing stream size might not be expected where small streams provide poor conditions for the survival of fish older than age- 0 .

The presence of barriers to upstream migration obviously influences the extent of anadromy in migratory salmonids, and barriers commonly influence population genetics (Clemento et al. 2009). However, members of upstream populations may become anadromous when transported below barriers (Wilzbach et al. 2012). While barriers are obviously important, they can be difficult to define with certainty: small changes in the structure of natural barriers can make them passable and the effectiveness of barriers is often flow-dependent. Nevertheless, barriers remain important to resource management, in that regulatory approaches to streams accessible to anadromous fish may differ from approaches applied to streams above barriers.

We examined the distribution of anadromy in O. mykiss in the Eel River Drainage for two main reasons: 1 ) resource managers sought more information on the effectiveness of a specific prospective barrier (Eaton Roughs on the Van Duzen River) to upstream migration where a large amount of suitable habitat for O. mykiss is available; and 2) we sought to test the applicability of relationships observed in other systems between $O$. mykiss anadromy and the environmental factors of upstream distance and stream size.

\section{METHODS}

\section{Study Area}

The Eel River Drainage of northwestern California is the third largest drainage in the state, covering $9542 \mathrm{~km}^{2}$ of largely forest and oak woodland subject to a Mediterranean climate with wet winters and dry summers. It is characterized by unstable underlying rock, significant tectonic activity, and extreme sediment yields (Wheatcroft and Sommerfield 2005). The Eel River historically supported robust populations of anadromous salmonids including Chinook salmon (Oncorhynchus tshawytscha), Coho Salmon (O. kisutch) and steelhead/rainbow trout; all have substantially declined. Yoshiyama and Moyle (2010) suggest that for winter and summer runs of steelhead: "Based on habitat availability and the 
few population estimates that exist, historic numbers were likely $100,000-150,000$ adults per year (both runs combined), declining to $10,000-15,000$ by the 1960s. Present numbers are probably considerably less than 1,000 fish in both runs." However, Yoshiyama and Moyle (2010) also suggest that the distribution of steelhead/rainbow trout in the Eel River has declined much less than the species' abundance. The Eel River is also the southern-most drainage in the range of coastal cutthroat trout $(O$. clarki clarki), but that species' distribution within the drainage is limited to a few tributaries close to the coast.

\section{Field Methods}

We collected juvenile $O$. mykiss by electrofishing at 52 sites in the Eel River Drainage from July to October of 2012. Water year 2012 was relatively dry, with a mean annual streamflow $65 \%$ of the long-term average at two gaging sites in the Drainage. We selected sites to cover a broad range of distance to the ocean and stream size (Figure 1). We also included samples above three prospective barriers, with a particular focus above Eaton Roughs on the Van Duzen River, because resource managers had expressed specific interest in that area of the stream network. Eaton Roughs has been classified as a barrier to anadromous salmonids by resource management agencies. Using information in Reiser and Peacock (1985), we defined additional prospective barriers as features requiring leaps of $3.3 \mathrm{~m}$ or more where we judged "take-off" conditions to be good or leaps of $2 \mathrm{~m}$ or more where "take-off" conditions were considered poor. After euthanizing them with an overdose of MS-222, we preserved whole fish in $90 \%$ ethanol for later extraction of otoliths.

\section{Laboratory Methods}

We rinsed one otolith from each fish in deionized water to remove any remaining biological material from the surface and allowed it to air dry. Cleaned otoliths were embedded in Buehler Epothin epoxy and sectioned through the nucleus in the transverse plane with two wafering blades on a Buehler Isomet low-speed saw. We placed the transverse sections face down on a sheet of adhesive paper, then embedded them in epoxy within a $2.54-\mathrm{cm}$ diameter lucite ring. Each ring contained $20-22$ otolith sections. After curing, we polished the exposed otolith sections with $30-\mu \mathrm{m}, 9-\mu \mathrm{m}$, and $3-\mu \mathrm{m}$ polishing papers and finally in a slurry of $0.05-\mu \mathrm{m}$ alumina polish.

We determined maternal origin using one or two analytical steps, as needed. First, we analyzed elemental strontium ( $\mathrm{Sr}$ ) concentration in otolith core regions and compared it to $\mathrm{Sr}$ concentration in the first-summer growth regions using methods described by Zimmerman et al. (2009). Otolith $\mathrm{Sr}$ concentrations were measured using laser ablation inductively coupled, plasma mass spectrometry (LA-ICP-MS) using an Agilent 7500c, quadrupole mass spectrometer and a New Wave $213 \mathrm{~nm}$ excimer laser at the University of Alaska Fairbanks Advanced Instrumentation Laboratory. Starting in the primordia, transects were ablated perpendicular to growth increments in one otolith per captured fish. Transects extended into the otolith mounting medium beyond the distal edge of the otolith. Count (intensity) data were collected for the elements strontium $\left({ }^{88} \mathrm{Sr}\right)$ and calcium $\left({ }^{43} \mathrm{Ca}\right)$. Calcium was used as an internal standard, and background-subtracted counts of $\mathrm{Sr}$ were adjusted to $\mathrm{Ca}$ and calibrated to glass standard reference material (NIST 610, National Institute of Standards and Testing). Calibration standards were run between every $10-12$ samples. Laser speed was set at $5 \mu \mathrm{m} / \mathrm{s}$ with a $25-\mu \mathrm{m}$ spot diameter on a single-pass transect set to $80 \%$ power. The elemental count per second output of the LA-ICP-MS was then converted to concen- 


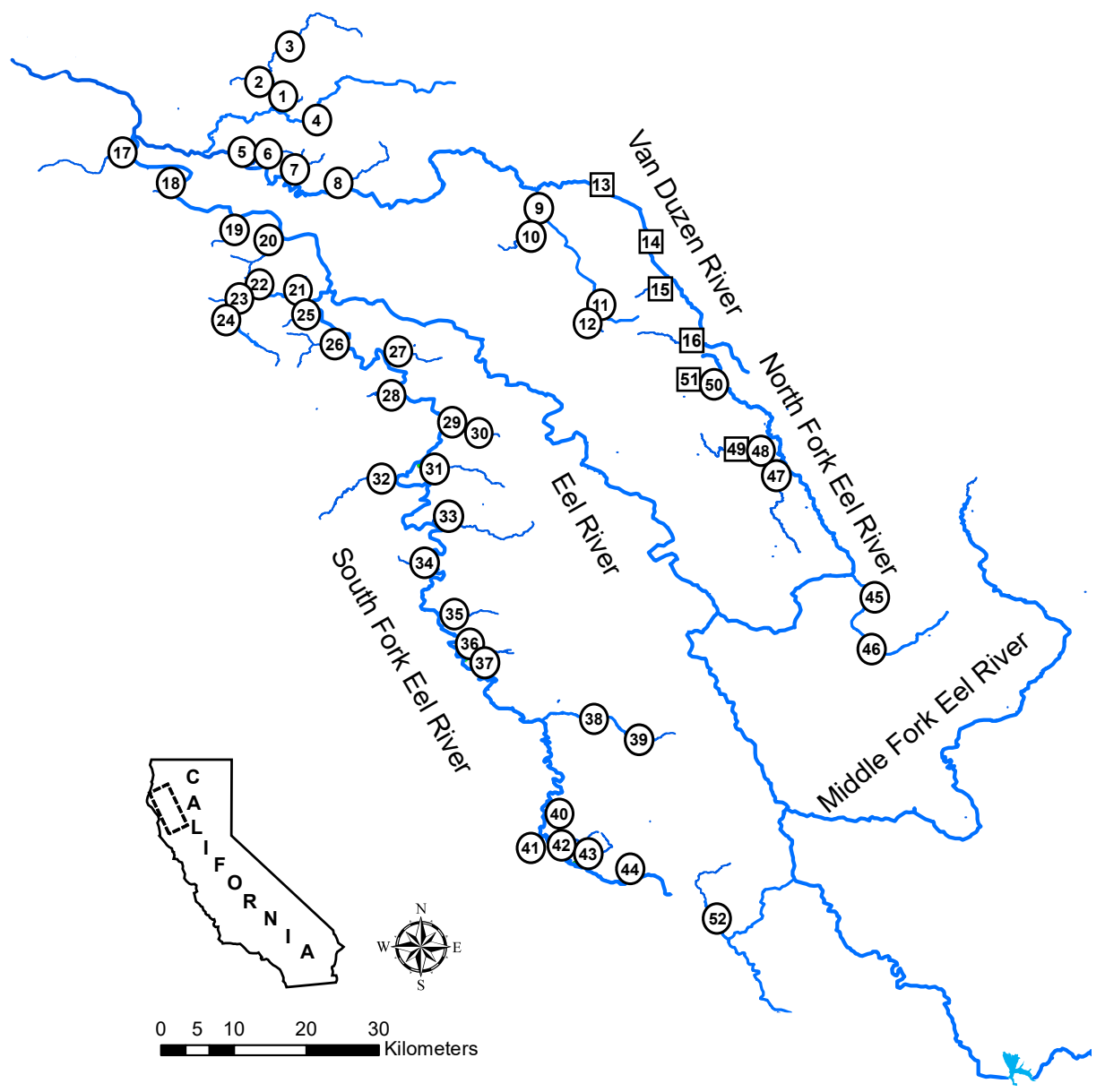

Figure 1. Sampling sites for a study of anadromy and residency of Oncorhynchus mykiss in the Eel River Drainage of northwestern California: 1 - Lawrence Creek (1); 2 - Corner Creek; 3 - Lawrence Creek 2; 4 - North Fork Yager Creek; 5 - Fiedler Creek; 6 - Cummings Creek; 7 - Hely Creek; 8 - Grizzly Creek; 9 - South Fork Van Duzen River (1); 10 - Butte Creek; 11 - South Fork Van Duzen River (2); 12 - Lost Canyon Creek; 13 - Van Duzen River (1); 14 - Van Duzen River (2); 15 - Black Lassic Creek; 16 - West Fork Van Duzen River; 17 - Price Creek; 18 - Dean Creek (A); 19 - Jordan Creek; 20 - Bear Creek; 21 - Cow Creek; 22 - Albee Creek; 23 - Cuneo Creek; 24 - South Fork Cuneo Creek; 25 - Decker Creek; 26 - Canoe Creek; 27 - Elk Creek; 28 - Salmon Creek; 29 Ohman Creek (1); 30 - Ohman Creek (2); 31 - Dean Creek (B); 32 - Redwood Creek (A); 33 - East Branch South Fork Eel River; 34 - Durphy Creek; 35 - McCoy Creek; 36 - Bridges Creek; 37 - Dora Creek; 38 - Rattlesnake Creek (1); 39 - Rattlesnake Creek (2); 40 - Deer Creek; 41 - Redwood Creek (B); 42 - Kenny Creek; 43 - Mud Creek; 44 - Windem Creek; 45 - Hulls Creek (1); 46 - Hulls Creek (2); 47 - Salt Creek; 48 - Bluff Creek (1); 49 - Bluff Creek (2); 50 - Panther Creek (1); 51 - Panther Creek (2); 52 - Long Valley Creek. Square symbols identify sites above prospective barriers to anadromous fish. Numbers in parentheses distinguish multiple sampling sites on the same stream; letters in parentheses distinguish different streams with the same name. 
tration. Relatively low $\mathrm{Sr}$ concentrations ( $\mathrm{Sr}$ concentration $<1000 \mathrm{ppm}$ ) in the summer growth regions of most otoliths allowed the determination of maternal origin using the $\mathrm{Sr}$ concentration of the core regions, following the methods of Zimmerman et al. (2009). For these otoliths, if mean $\mathrm{Sr}$ concentration in the core region significantly exceeded that of the mean summer growth region (one-tailed t-test), we classified fish as steelhead progeny, otherwise we classified fish as resident progeny.

However, high $\mathrm{Sr}$ concentrations in the summer growth regions of some otoliths indicated high ambient $\mathrm{Sr}$ in some streams. For otoliths with $\mathrm{Sr}$ concentrations in the summer growth region $>1000 \mathrm{ppm}$, we determined maternal origin of otoliths in a second analytical step, using ${ }^{87} \mathrm{Sr} /{ }^{86} \mathrm{Sr}$ ratios. We measured otolith ${ }^{87} \mathrm{Sr} r{ }^{86} \mathrm{Sr}$ ratios using laser ablation-inductively coupled plasma mass spectrometry (LA-MC-ICP-MS) in the W.M. Keck Collaboratory for Plasma Mass Spectrometry at Oregon State University, using a NuPlasma multi-collector ICP-MS instrument and a New Wave DUV193 excimer laser. Analysis techniques followed Miller and Kent (2009).

Ablation used a pulse rate of $10 \mathrm{~Hz}$, a 70- $\mu \mathrm{m}$ diameter spot size, and the laser spot was translated across the sample at $\sim 2 \mu \mathrm{m} / \mathrm{s}$. Backgrounds were measured prior to analysis for $60 \mathrm{~s}$ and measured background intensities were subtracted from intensities measured during otolith ablation. Mass biases were corrected by reference to an ${ }^{86} \mathrm{Sr} r{ }^{88} \mathrm{Sr}$ ratio of 0.1194 using an exponential mass bias correction scheme. The low rubidium $(\mathrm{Rb}) / \mathrm{Sr}$ ratio of otolith material indicated minor isobaric interference of ${ }^{87} \mathrm{Rb}$ on ${ }^{87} \mathrm{Sr}$, and we corrected this using measured ${ }^{85} \mathrm{Rb}$ to calculate the contribution of ${ }^{87} \mathrm{Rb}$. Typical precision and accuracy for measured ${ }^{87} \mathrm{Sr} /{ }^{86} \mathrm{Sr}$ ratios is $\pm 0.0001-0.0002$ (two $S E$ ). We assessed accuracy during analyses via measurement of a deep-sea gastropod shell from the Gulf of Mexico with ${ }^{87} \mathrm{Sr} /{ }^{86} \mathrm{Sr} 0.70919 \pm 0.00008$. We determined maternal origin using ${ }^{87} \mathrm{Sr} /{ }^{86} \mathrm{Sr}$ following methods in Courter et al. (2013): the otolith core regions of steelhead progeny had ${ }^{87} \mathrm{Sr} /{ }^{86} \mathrm{Sr}$ ratios $>0.7080$ while those of resident progeny matched the ${ }^{87} \mathrm{Sr} /{ }^{86} \mathrm{Sr}$ ratio found in the first summer growth region. For the progeny of resident mothers, ratios of ${ }^{87} \mathrm{Sr} /{ }^{86} \mathrm{Sr}$ in first summer growth regions ranged from 0.7021 to 0.7050 and thus did not overlap marine values (Brennan et al. 2015).

\section{Analysis}

In general, we included two fish from each sampling site in the analysis, one assumed to be age- 0 and the other post-age- 0 , usually age- 1 . We based age estimates on size-frequency distributions. One below-barrier site (Dora Creek) only yielded one fish. Because of our particular interest in the upper Van Duzen River, we included three sampling sites from that area and as many as four fish per site in the analysis. We selected all fish included in the analysis a priori.

We modeled the occurrence of juvenile steelhead with anadromous mothers using logistic regression and three predictors that have influenced the distribution of anadromy in previous studies of salmonids: distance from the ocean, stream size, and the presence of barriers. We used estimates of mean annual run-off to characterize stream size, using an equation for rainfall-dominated watersheds from Sanborn and Bledsoe (2006) that uses drainage area, precipitation, and potential evapotranspiration as independent variables. We included six candidate models chosen a priori in the model selection process and compared them using Akaike's Information Criterion corrected for small sample sizes (AICc; Burnham 
and Anderson 2002).

Following Mills et al. (2012), we also tested for non-random distribution of life histories using a chi-square test of the frequency of sites at which the sampled fish had the same versus different maternal types, at all sites where two fish were collected and also tested the subset of sites below barriers where two fish were collected. In these analyses, the expected number of sites with two fish of the same maternal type was the sum of the squares of the proportional frequencies of the two types multiplied by the total number of sites (Mills et al. 2012).

\section{RESULTS}

We included otoliths from 106 fish in the otolith analyses. The analysis indicated that 61 of 91 fish sampled below barriers had anadromous mothers, while 1 of 15 fish sampled above prospective barriers ( 1 of the 11 fish collected upstream of Eaton Roughs) had an anadromous mother. With the exception of the predictable influence of barriers, both residency and anadromy were broadly distributed among the sampling sites. We found juveniles with resident mothers at 21 of 46 sites below barriers. Overall, sites with two individuals with the same maternal type occurred more frequently than expected at random (36 out of 50 sites where two individuals were collected, $\mathrm{P}=0.04)$, but the pattern for sites below barriers was not distinguishable from a random distribution ( 32 out of 45 sites, $\mathrm{P}=0.13$ ).

Among the candidate models tested for their ability to predict anadromy by $O$. mykiss in the Eel River Drainage, only the model with the presence / absence of prospective barriers as the only predictor received clear support, as indicated by AIC weight (Table 1). More complex models that included barriers and either distance from the ocean, stream size, or both, yielded $\triangle \mathrm{AICc}$ values within the range that would result from the addition of uninformative parameters (Arnold 2010). This conclusion is supported by the occurrence of anadromy over wide ranges of both stream size and distance from the ocean (Figure 2), and the identical pattern of misclassifications in the barrier-only model versus models that included barriers and additional parameters (Table 1). Finally, the model that used only stream size (as represented by mean annual run-off) as a predictor performed poorly.

\section{DISCUSSION}

Table 1. Model fit information for the six candidate models used to predict the occurrence of anadromy in Oncorhynchus mykiss for 106 fish from 52 sites in the Eel River Drainage of northwestern California. Distance indicates the distance of sites from the ocean; Mean Annual Runoff is an index of stream size.

\begin{tabular}{lcccc}
\hline Model & AICc & $\begin{array}{c}\text { AIC } \\
\text { weight }\end{array}$ & $\begin{array}{c}\text { \% False } \\
\text { positives }\end{array}$ & $\begin{array}{c}\text { \% False } \\
\text { negatives }\end{array}$ \\
\hline Barriers & 0.0 & 0.52 & 31 & 7 \\
Barriers + Distance & 1.8 & 0.21 & 31 & 7 \\
Barriers + MeanAnnualRunoff & 2.0 & 0.19 & 31 & 7 \\
Barriers + MeanAnnualRunoff + Distance & 3.8 & 0.08 & 31 & 7 \\
Intercept only & 18.6 & $<0.01$ & & \\
MeanAnnualRunoff & 20.0 & $<0.01$ & 36 & 33 \\
\hline
\end{tabular}




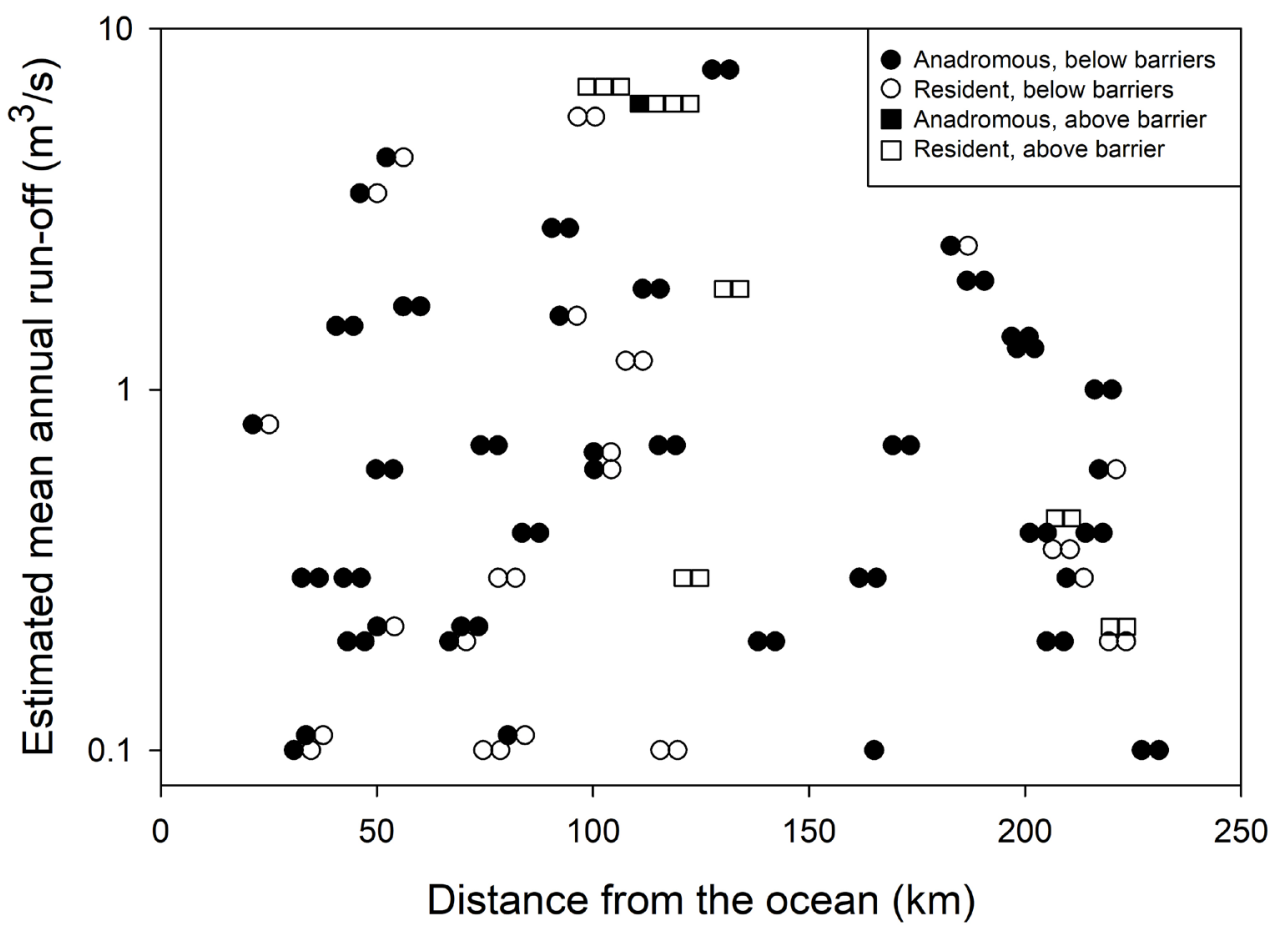

Figure 2. The occurrence of juvenile steelhead/rainbow trout with anadromous versus resident mothers (as indicated by strontium isotope analysis of otoliths), plotted against distance to the ocean and mean annual run-off (an index of stream size). Symbols differentiate sampling sites above and below prospective barriers to upstream migration. Each symbol represents an individual fish. Some overlapping symbols have been slightly offset for clarity.

While barriers to upstream migration have an obvious role in determining site-specific life history alternatives for $O$. mykiss, this study highlights the uncertainty of barrier identification. Our finding of a single juvenile fish with an anadromous parent upstream of Eaton Roughs, coupled with a recent observation of an adult steelhead upstream of Eaton Roughs (Kannry et al. 2020), suggest that it functions as a partial barrier. At many prospective barriers, fish passage will depend on the timing and magnitude of streamflows in relation to the presence of migrating adults. In addition to streamflow effects, even minor changes in the arrangement of objects forming barriers may strongly affect the ability of fish to pass upstream. "Partial" barriers to $O$. mykiss are difficult to detect because access opportunities can be fleeting, relatively few steelhead are currently available to use those opportunities, and those that do may be strongly outnumbered by resident fish upstream, lowering the probability of detecting the offspring of anadromous individuals. Sample size limitations due to the lethal sampling required for otolith analysis exacerbates the last point. Finally, rare anadromous adults can be difficult to detect in large, turbid rivers.

The lack of a detectable influence of stream size on anadromy in O. mykiss in the Eel River Drainage contrasts with the results from the John Day River in Oregon (Mills et 
al. 2012), where anadromy of $O$. mykiss increased with stream size. This difference seems reasonable given the sample sites in the present study included small streams where the resident life history could be difficult to maintain because of limited dry-season habitat for adult resident fish. In small tributaries, the combination of low streamflows, high sediment loads and low habitat complexity may create high risk and limited feeding opportunities for $O$. mykiss older than age- 0 . Such streams may function principally as nursery areas for age- 0 individuals, as suggested by the observed positive relationship between streamflow and density of $O$. mykiss older than age- 0 in tributaries of the South Fork Eel River (Harvey et al. 2002).

Freshwater migration distance also did not influence the frequency of anadromy in our analysis. Freshwater migration distances did not exceed $250 \mathrm{~km}$ in our dataset and such distances are modest compared to those traversed by anadromous fish in larger drainages such as the Sacramento/San Joaquin and the Columbia. However, Kristofferson (1994) proposed that severe predation risk for migrant arctic charr (Salvelinus alpinus) could result in a distance effect on the frequency of anadromy even in the range of 0.3 to $7 \mathrm{~km}$ of migration distance. Adult steelhead in the Eel River may benefit from relatively modest predation risk in comparison to the arctic charr studied by Kristofferson (1994), because the former usually migrate during high, turbid streamflows.

While studies of anadromy versus residency in O. mykiss often focus on the persistence of the genetic potential for anadromy upstream of barriers, our study indicates the need to consider - under current conditions - the downstream distribution of residency. Juvenile fish with resident mothers were broadly distributed: we found them at $46 \%$ of the sites where no downstream barriers obstructed returning anadromous adults. We captured fish with resident mothers at several sites not far downstream from barriers to upstream migration. "Leaky" above-barrier resident populations may be contributing individuals to below-barrier reaches accessible to anadromous fish. In any case, reproduction by resident females made a noteworthy contribution to juvenile $O$. mykiss abundance in reaches accessible to anadromous fish. In addition, previous research has established that resident $O$. mykiss can contribute substantially to the anadromous component of some salmonid populations (Christie et al. 2011). These observations support the idea that conditions for fish older than age- 0 throughout the stream network of the Eel River Drainage deserve special consideration from resource managers. High-quality freshwater conditions for larger fish benefit the $O$. mykiss population not only because of the relative value of large smolts to the population, but because of the potentially significant contribution of resident adults to population dynamics throughout the system. Unfortunately, a variety of factors have degraded freshwater conditions for resident salmonids in the Eel River Drainage: higher water temperatures, increased sediment loads that have reduced habitat complexity, the presence of alien species that may increase both competition (Reese and Harvey 2002) and predation (Nakamoto and Harvey 2003), and increased water diversion for domestic and agricultural use.

\section{ACKNOWLEDGMENTS}

We received field assistance from B. Nakamoto, J. White, and J. Wiesenfeld. K. Kenfield provided key contributions during the design of the study. K. Pope's review improved the manuscript. The U.S. Geological Survey Forest and Rangeland Ecosystem Science Center in Corvallis, Oregon provided funding for the study. Any use of trade, firm, or product names is for descriptive purposes only and does not imply endorsement by the U.S. Government. 


\section{LITERATURE CITED}

Arnold, T. W. 2010. Uninformative parameters and model selection using Akaike's Information Criterion. Journal of Wildlife Management 74:1175-1178.

Brennan, S. R., D. P. Fernandez, C. E. Zimmerman, T. E. Cerling, R. J. Brown, and M. J. Wooller. 2015. Strontium isotopes in otoliths of a non-migratory fish (slimy sculpin): implications for provenance studies. Geochimica et Cosmochimica Acta 149:32-45.

Burnham, K. P., and D. R. Anderson. 2002. Model selection and multimodel inference: a practical information-theoretic approach. 2nd edition. Springer-Verlag, New York, NY, USA.

Christie, M. R., M. L. Marine, and M. S. Blouin. 2011. Who are the missing parents? Grandparentage analysis identifies multiple sources of gene flow into a wild population. Molecular Ecology 20:1263-1276.

Clemento, A. J., E. C. Anderson, D. Boughton, D. Girman, and J. C. Garza. 2009. Population genetic structure and ancestry of Oncorhynchus mykiss populations above and below dams in south-central California. Conservation Genetics 10:1321-1336.

Courter, I. I, D. B. Child, J. A. Hobbs, T. M. Garrison, J. J. G. Glessner and S. Duery. 2013. Resident rainbow trout produce anadromous offspring in a large interior watershed. Canadian Journal of Fisheries and Aquatic Sciences 70(5):701-710.

Donohoe, C. J., P. B. Adams, and C. F Royer. 2008. Influence of water chemistry and migratory distance on ability to distinguish progeny of sympatric resident and anadromous rainbow trout (Oncorhynchus mykiss). Canadian Journal of Fish and Aquatic Sciences 65(6):1060-1075.

Hale, M. C., F. P. Thrower, E. A. Berntson, M. R. Miller, and K. M. Nichols. 2013. Evaluating adaptive divergence between migratory and nonmigratory ecotypes of a salmonid fish, Oncorhynchus mykiss. G3: Genes, Genomes, Genetics 3(8):12731285.

Harvey, B. C., J. L. White, and R. J. Nakamoto. 2002. Habitat relationships and larval drift of native and nonindigenous fishes in neighboring tributaries of a coastal California river. Transactions of the American Fisheries Society 131:159-170.

Kannry, S. H., S. M. O’Rourke, S. J. Kelson, and M. R. Miller. 2020. On the ecology and distribution of Steelhead (Oncorhynchus mykiss) in California's Eel River. Journal of Heredity 111(6):548-563.

Kelson, S. J., S. M. Carlson, and M. R. Miller. 2020. Indirect genetic control of migration in a salmonid fish. Biology Letters 16(8):art20200299.

Kendall, N. W., J. R. McMillan, M. R. Sloat, T. W. Buehrens, T. P. Quinn, G. R. Pess, K. V. Kuzishchin, M. M. McClure, and R. W. Zabel. 2015. Anadromy and residency in steelhead and rainbow trout (Oncorhynchus mykiss): a review of the processes and patterns. Canadian Journal of Fisheries and Aquatic Sciences 72(3):319-342.

Knudsen, E. E., and J. H. Michael, Jr., editors. 2009. Pacific salmon environmental and life history models: advancing science for sustainable salmon in the future. Symposium 71, American Fisheries Society, Bethesda, MD, USA.

Kristoffersen, K. 1994. The influence of physical watercourse parameters on the degree of anadromy in different lake populations of Arctic charr (Salvelinus alpinus (L.)) in northern Norway. Ecology of Freshwater Fish 3(2):80-91.

Liberoff, A. L., A. P. Quiroga, C. M. Riva-Rossi, J. A. Miller, and M. A. Pascual. 2015. 
Influence of maternal habitat choice, environment and spatial distribution of juveniles on their propensity for anadromy in a partially anadromous population of rainbow trout (Oncorhynchus mykiss). Ecology of Freshwater Fish 24(3):424434.

McMillan, J. R., S. L. Katz, and G. R. Pess. 2007. Observational evidence of spatial and temporal structure in a sympatric anadromous (winter steelhead) and resident rainbow trout mating system on the Olympic Peninsula, Washington. Transactions of the American Fisheries Society 136:736-748.

Miller, J. A., and A. J. R. Kent. 2009. The determination of maternal run time in juvenile Chinook salmon (Oncorhynchus tshawytscha) based on $\mathrm{Sr} / \mathrm{Ca}$ and ${ }^{87} \mathrm{Sr} /{ }^{86} \mathrm{Sr}$ within otolith cores. Fisheries Research 95:373-378.

Mills, J. S., J. B. Dunham, G. H. Reeves, J. R. McMillan, C. E. Zimmerman, and C. E. Jordan. 2012. Variability in expression of anadromy by female Oncorhynchus mykiss within a river network. Environmental Biology of Fishes 93(4):505-517.

Nakamoto, R. J., and B. C. Harvey. 2003. Spatial, seasonal, and size-dependent variation in the diet of Sacramento pikeminnow in the Eel River, northwestern California. California Fish and Game 89:30-45.

Ohms, H.A., M. R. Sloat, G. H. Reeves, C. E. Jordan, and J. B. Dunham. 2014. Influence of sex, migration distance, and latitude on life history expression in steelhead and rainbow trout (Oncorhynchus mykiss). Canadian Journal of Fisheries and Aquatic Sciences 71(1):70-80.

Pearse, D. E., M. R. Miller, A. Abadía-Cardoso, and J. C. Garza. 2014. Rapid parallel evolution of standing variation in a single, complex, genomic region is associated with life history in steelhead/rainbow trout. Proceedings of the Royal Society of London B 281:20140012.

Reese, C. D., and B. C. Harvey. 2002. Temperature-dependent competition between juvenile steelhead and Sacramento pikeminnow. Transactions of the American Fisheries Society 131:599-606.

Reiser, D. W., and R. T. Peacock. 1985. A technique for assessing upstream fish passage problems at small-scale hydropower developments. Pages 423-432 in F. W. Olson, R. G. White, and R. H. Hamre, editors. Proceedings of the Symposium on Small Hydropower and Fisheries. American Fisheries Society, Bethesda, MD, USA.

Sanborn, S. C., and B. P. Bledsoe. 2006. Predicting streamflow regime metrics for ungauged streams in Colorado, Washington, and Oregon. Journal of Hydrology 325:241-261.

Sloat, M. R., and G. H. Reeves. 2014. Individual condition, standard metabolic rate, and rearing temperature influence steelhead and rainbow trout (Oncorhynchus mykiss) life histories. Canadian Journal of Fisheries and Aquatic Sciences 71(4): 491-501.

Wheatcroft, R. A., and C. K. Sommerfield. 2005. River sediment flux and shelf sediment accumulation rates on the Pacific Northwest margin. Continental Shelf Research 25(3):311-332.

Wilzbach, M. A., M. J. Ashenfelter, and S. J. Ricker. 2012. Movement of resident rainbow trout transplanted below a barrier to anadromy. Transactions of the American Fisheries Society 141:294-304. 
Yoshiyama, R. M., and P. B. Moyle. 2010. Historical review of Eel River anadromous salmonids, with emphasis on Chinook salmon, coho salmon and steelhead. University of California, Davis, Center for Watershed Sciences Working Paper. Available from: https://watershed.ucdavis.edu/pdf/Yoshiyama-Moyle_Eel River Final Report 2010.pdf

Zimmerman, C. E., G. W. Edwards, and K. Perry. 2009. Maternal origin and migratory history of steelhead and rainbow trout captured in rivers of the Central Valley, California. Transactions of the American Fisheries Society 138:280-291.

Zimmerman, C. E., and G. H. Reeves. 2000. Population structure of sympatric anadromous and nonanadromous Oncorhynchus mykiss: evidence from spawning surveys and otolith microchemistry. Canadian Journal of Fisheries and Aquatic Sciences 57(10):2152-2162.

Zimmerman, C. E., and G. H. Reeves. 2002. Identification of steelhead and resident rainbow trout progeny in the Deschutes River, Oregon, revealed with otolith microchemistry. Transactions of the American Fisheries Society 131:986-993.

Submitted 19 March 2021

Accepted 3 May 2021

Associate Editor was K. Lindke

APPENDIX I. SAMPLING SITE CHARACTERISTICS.

\begin{tabular}{lccc}
\hline Watercourse & $\begin{array}{c}\text { Distance from the } \\
\text { ocean }(\mathrm{km})\end{array}$ & $\begin{array}{c}\text { Modeled mean annual } \\
\text { run-off }(\mathrm{m} 3 / \mathrm{s})\end{array}$ & Barrier \\
\hline Albee & 76.6 & 0.1 & No \\
Bear & 51.8 & 0.6 & No \\
Black Lassic & 122.8 & 0.3 & Yes \\
Bluff 1 & 208.4 & 0.4 & No \\
Bluff 2 & 208.9 & 0.4 & Yes \\
Bridges & 163.7 & 0.3 & No \\
Butte & 94.3 & 1.6 & No \\
Canoe & 76.0 & 0.7 & No \\
Corner & 52.1 & 0.2 & No \\
Cow & 71.5 & 0.2 & No \\
Cummings & 34.6 & 0.3 & No \\
Cuneo & 80.1 & 0.3 & No \\
Dean A & 32.8 & 0.1 & No \\
Dean B & 109.6 & 1.2 & No \\
Decker & 68.7 & 0.2 & No \\
Deer & 207.0 & 0.2 & No
\end{tabular}




\section{APPENDIX I. continued}

\begin{tabular}{|c|c|c|c|}
\hline Watercourse & $\begin{array}{l}\text { Distance from the } \\
\text { ocean }(\mathrm{km})\end{array}$ & $\begin{array}{l}\text { Modeled mean annual } \\
\text { run-off }(\mathrm{m} 3 / \mathrm{s})\end{array}$ & Barrier \\
\hline Dora & 165.1 & 0.1 & No \\
\hline Durphy & 140.2 & 0.2 & No \\
\hline East Br. South Fork & 129.6 & 7.7 & No \\
\hline Elk & 85.6 & 0.4 & No \\
\hline Fiedler & 35.6 & 0.1 & No \\
\hline Grizzly & 42.6 & 1.5 & No \\
\hline Hely & 45.2 & 0.2 & No \\
\hline Hulls 1 & 188.6 & 2.0 & No \\
\hline Hulls 2 & 198.9 & 1.4 & No \\
\hline Jordan & 44.3 & 0.3 & No \\
\hline Kenny & 216.0 & 0.4 & No \\
\hline Lawrence 1 & 48.1 & 3.5 & No \\
\hline Lawrence 2 & 58.1 & 1.7 & No \\
\hline Long Valley & 218.1 & 1.0 & No \\
\hline Lost Canyon & 117.6 & 0.1 & No \\
\hline McCoy & 171.4 & 0.7 & No \\
\hline Mud & 219.1 & 0.6 & No \\
\hline North Fork Yager & 54.2 & 4.4 & No \\
\hline Ohman 1 & 102.2 & 0.6 & No \\
\hline Ohman 2 & 102.3 & 0.6 & No \\
\hline Panther 1 & 221.4 & 0.2 & No \\
\hline Panther 2 & 221.6 & 0.2 & Yes \\
\hline Price & 23.3 & 0.8 & No \\
\hline Rattlesnake 1 & 184.8 & 2.5 & No \\
\hline Rattlesnake 2 & 203.1 & 0.4 & No \\
\hline Redwood A & 113.5 & 1.9 & No \\
\hline Redwood B & 211.6 & 0.3 & No \\
\hline Salmon & 92.5 & 2.8 & No \\
\hline Salt & 200.2 & 1.3 & No \\
\hline South Fork Cuneo & 82.3 & 0.1 & No \\
\hline South Fk. Van Duzen 1 & 98.5 & 5.7 & No \\
\hline South Fk. Van Duzen 2 & 117.2 & 0.7 & No \\
\hline Upper Van Duzen 1 & 102.5 & 6.9 & Yes \\
\hline Upper Van Duzen 2 & 114.6 & 6.2 & Yes \\
\hline West Fork Van Duzen & 132.1 & 1.9 & Yes \\
\hline Windem & 229.0 & 0.1 & No \\
\hline
\end{tabular}

